\title{
22. PLASTIC DEFORMATION AT AN OCEANIC SPREADING RIDGE: A MICROSTRUCTURAL STUDY OF THE SITE 735 GABBROS (SOUTHWEST INDIAN OCEAN) ${ }^{1}$
}

\author{
Mathilde Cannat ${ }^{2}$
}

\begin{abstract}
Microstructural analysis suggests that some Site 735 gabbros were deformed in the crystal mush stage, before they had completely crystallized. Later, solid-state deformation began in granulite-facies metamorphic conditions. At this stage, temperature-dependent diffusion processes may have controlled the plastic deformation of these gabbros, and mylonites formed only in intervals containing more than $10 \% \mathrm{Fe}-\mathrm{Ti}$ oxides. Most oxides in these mylonites are interpreted as magmatic in origin. A sharp change of deformation processes occurred as temperature decreased to the stability conditions of amphibolite-facies metamorphic assemblages: dislocation slip in plagioclase may have become the leading plastic flow mechanism. This change of deformation processes coincides with increased availability of hydrothermal water and with a marked decrease of the plagioclase recrystallized grain size. This reduction in recrystallized grain size is thought to result from an increase of the deviatoric stress, and thus from an increase of the yield strength of the gabbros. In amphibolite-facies metamorphic conditions, dynamic recrystallization of plagioclase locally caused strain-softening, leading to the formation of mylonites. Relict porphyroclasts (plagioclase, olivine, and pyroxenes) in these mylonites are fractured and boudinaged. The cracks produced by this brittle failure are filled with green to brown hydrothermal hornblende.
\end{abstract}

\section{INTRODUCTION}

A total of $500 \mathrm{~m}$ of gabbro was drilled at Site 735 during Ocean Drilling Program (ODP) Leg 118. Site 735 lies on a shallow platform near the east wall of the Atlantis II Fracture Zone, about $100 \mathrm{~km}$ south of the Southwest Indian Ridge axis (Fig. 1). The pattern of magnetic anomalies indicates that the crust here was accreted at the ridge about $11 \mathrm{~m}$.y. ago (Dick et al., this volume). This is supported by a zircon isotopic age of 11.3 Ma (J. Mattinson, pers. comm., 1989).

About $30 \%$ of the $435 \mathrm{~m}$ of gabbro recovered at Site 735 is plastically deformed along flat to moderately dipping, normal shear zones (Cannat et al., this volume). The synkinematic assemblages in these shear zones correspond to metamorphic conditions that range from granulite to lower amphibolite facies (Stakes et al., this volume). There is no evidence in the hole for significant ductile deformation below the stability temperature of actinolitic hornblende, and the offset accommodated by brittle failure of the gabbros is limited. Deformation at Site 735 thus occurred when the gabbros were still hot, probably in the vicinity of the Southwest Indian Ridge axis (Cannat et al., this volume).

The distribution of the synkinematic assemblages in the Site 735 deformed gabbros indicates that this deformation occurred at progressively decreasing temperatures (Stakes et al., this volume), as may be expected in an oceanic domain, where newly accreted lithosphere spreads away from a ridge axis thermal high. Water-rich hydrothermal fluids circulated in the gabbros during this plastic deformation, and in many intervals, the temperature decrease during deformation correlates with an increase in the water/rock ratio (Stakes et al., this volume).

Here, I use the microstructures and the mineral preferred orientations associated with ductile deformation to infer flow mechanisms and the relative intensity of deviatoric stresses in

\footnotetext{
1 Von Herzen, R. P., Robinson, P. T., et al., 1991. Proc. ODP, Sci. Results, 118: College Station, TX (Ocean Drilling Program).

${ }^{2}$ GDR "Génése et Evolution des Domaines Océaniques," UBO, 6 Av. Le Gorgeu, 29287 Brest Cedex, France.
}

the Site 735 deformed gabbros. These results are used to interpret the tectonic evolution of these gabbros (Cannat et al., this volume). These results should also be relevant to more general studies of rheological behavior of the oceanic lithosphere near a spreading ridge axis.

Most Site 735 gabbros contain more than $50 \%$ plagioclase. This mineral thus may be expected to have controlling influence during plastic deformation. In the following microstructural analysis, I chose plagioclase as the key mineral for textural and preferred orientation research. Among the mafic minerals, I emphasize olivine because its dislocation substructure can be observed readily under an optical microscope, using the oxidation technique described by Kohlstedt et al. (1976). The anorthite (An) content of Site 735 magmatic plagioclase varies between $25 \%$ and $80 \%$. Because the rheological properties of plagioclase vary with its An content (Gandais and Willaime, 1984), all fabric measurements were performed on samples having similar plagioclase An contents $\left(A n_{35}\right.$ to $\left.A n_{50}\right)$. However, textural observations of samples having a different An content suggest that composition did not control the modes of plastic deformation of plagioclase at Site 735. In samples deformed in the stability conditions of granulite facies or hornblende-bearing amphibolite-facies metamorphic assemblages, the An content of the dynamically recrystallized plagioclase is the same as that of the neighboring magmatic porphyroclasts (Stakes et al., this volume). There is thus no composition-related rheological contrast to be expected between magmatic and recrystallized plagioclase. However, in samples deformed at temperatures corresponding to the stability of actinolitic hornblende, plagioclase neoblasts are distinctly less calcic than magmatic porphyroclasts and than neoblasts produced at earlier, higher temperature stages of the deformation (Stakes et al., this volume). In this paper, I do not investigate the possible rheological changes induced by this compositional variation. I concentrate on gabbros deformed either in granulite-facies or in hornblendebearing amphibolite-facies metamorphic conditions.

Some Site 735 gabbros display a foliation marked by the planar-shaped fabric of the plagioclase, clinopyroxene, and olivine crystals, with little or no recrystallization of these 


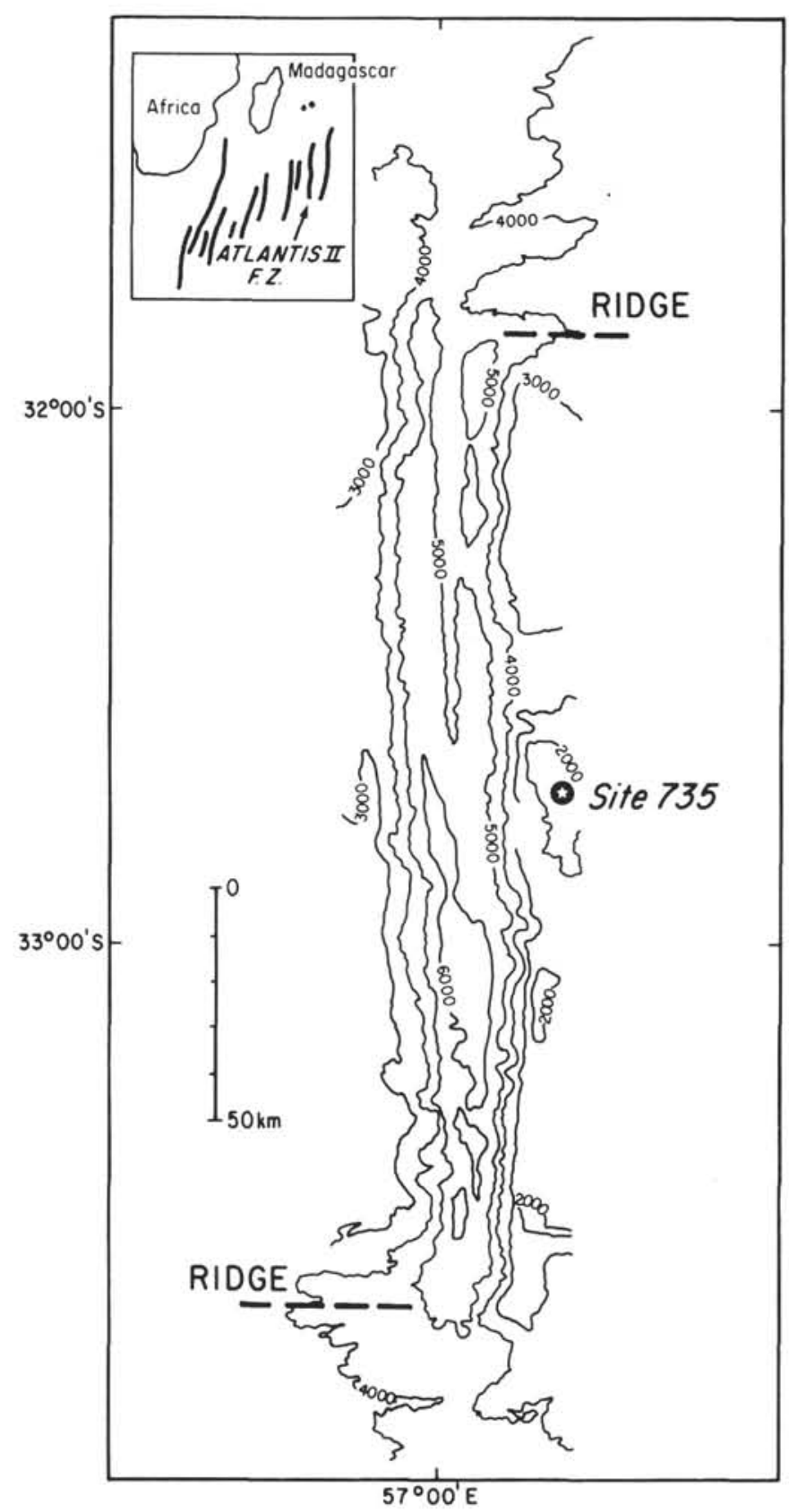

Figure 1. Bathymetric map of the Atlantis II transform fault, showing the location of Site 735. Contour intervals at $1000 \mathrm{~m}$ (Survey from Conrad cruise 27-09, 1986, H. Dick, Chief Scientist, with D. Gallo and R. Tyce).

minerals (Fig. 2A; Fig. 3). This texture is interpreted here as resulting from laminar viscous flow of the progressively solidifying gabbros.

The solid-state plastic deformation textures in Site 735 gabbros range from weakly recrystallized and unfoliated (Fig. $4 \mathrm{~A}$ ), to extensively recrystallized and mylonitic (Fig. 4B). These textural differences are thought to reflect variable finite strain intensities. In addition, the recrystallized grain size is not unique throughout the hole, and shear zones having very small recrystallized grain sizes frequently cut deformed gabbros having larger recrystallized grain sizes (Cannat et al., this volume). These larger-grained recrystallized gabbros exhibit granulite-facies metamorphic assemblages, with no evidence for synkinematic circulation of hydrothermal water-rich fluids (Stakes et al., this volume). By contrast, the finer-grained recrystallized gabbros exhibit upper to lower amphibolitefacies metamorphic assemblages and ample evidence for synkinematic circulation of water-rich hydrothermal fluids (Stakes et al., this volume). Experimental evidence from metals, ceramics, and some minerals (Bird et al., 1969; Twiss, 1977; Mercier et al., 1977) indicates that, during steady-state plastic flow, the size of neoblasts produced by dynamic recrystallization decreases as the applied deviatoric stress increases, regardless of temperature or finite strain. The recrystallized grain size in Site 735 gabbros thus probably reflects the relative intensity of deviatoric stress during plastic deformation. A decrease in the size of recrystallized plagioclase in gabbros deformed at lower temperatures is consistent with an increase of the ductile strength expected in rocks when temperature decreases (see Kirby, 1985). The stress/ recrystallized grain size relationship in plagioclase has not been experimentally calibrated. Twiss (1977) proposed an "approximate theoretical relation," based on the equation of the dislocation strain energy in the grain boundary to that in the enclosed volume. Applied to the recrystallized grain sizes measured in the Site 735 gabbros, this relationship yields deviatoric stresses above $1.5 \mathrm{~kb}$ for the smallest neoblasts ( 5 to $10 \mu \mathrm{m})$, and below $1 \mathrm{~kb}$ for the largest ones (20 to $40 \mu \mathrm{m})$. These values are only indicative because (1) experimental calibration is not available and (2) the recrystallized grain size in many samples is not unique and probably resulted from two distinct recrystallization mechanisms (rotation recrystallization and migration recrystallization).

Microstructural study of the solid-state deformation in Site 735 gabbros has been organized around three questions: (1) what are the active flow mechanisms in the deformed gabbros having the largest recrystallized grain size (granulite-facies metamorphic conditions); (2) what are the active flow mechanisms in the deformed gabbros having smaller recrystallized grain sizes (amphibolite-facies metamorphic conditions); and (3) what are the strain-softening mechanisms that enabled the strain to concentrate in narrow mylonitic shear zones?

\section{VISCOUS FLOW IN PROGRESSIVELY SOLIDIFYING GABBROIC MAGMA}

Thick intervals of gabbro from the middle part of the hole (Cores 118-735B-36R to 118-735B-56R; 172-272 mbsf; Cannat et al., this volume) display a foliation marked by tablet-shaped clinopyroxene and olivine crystals in a matrix of elliptic anhedral to euhedral plagioclase (Fig. 2A). In some samples, the preferred orientation of the long axis of these tablets defines a faint lineation.

Despite their strong shape fabric, these minerals have not been intensely deformed. The clinopyroxene is neither kinked nor recrystallized. The olivine has not been recrystallized either, but many grains exhibit dislocations (observed in oxidized samples; technique described by Kohlstedt et al., 1976), indicating some degree of plastic deformation. However, the crystallographic fabric of olivine is very weak: there is a poor concentration of [010] perpendicular to the foliation, but [100] and [001] are scattered (Fig. 5B). The plagioclase often exhibits bent mechanical twins and lobate grain boundaries that suggest grain-boundary migration, but its recrystallization is limited (Fig. 2A). However, its crystallographic fabric is strong (Fig. 5A). [010] is preferentially perpendicular to foliation, and [100] forms a girdle parallel to foliation. This crystallographic fabric was constructed from U-stage measurements of the optical directions and of the albite $(010)$ or pericline twinning planes, using a computer program devised by Benn and Mainprice (1989). Contouring of diagrams was performed using an unpublished program by D. Mainprice. 

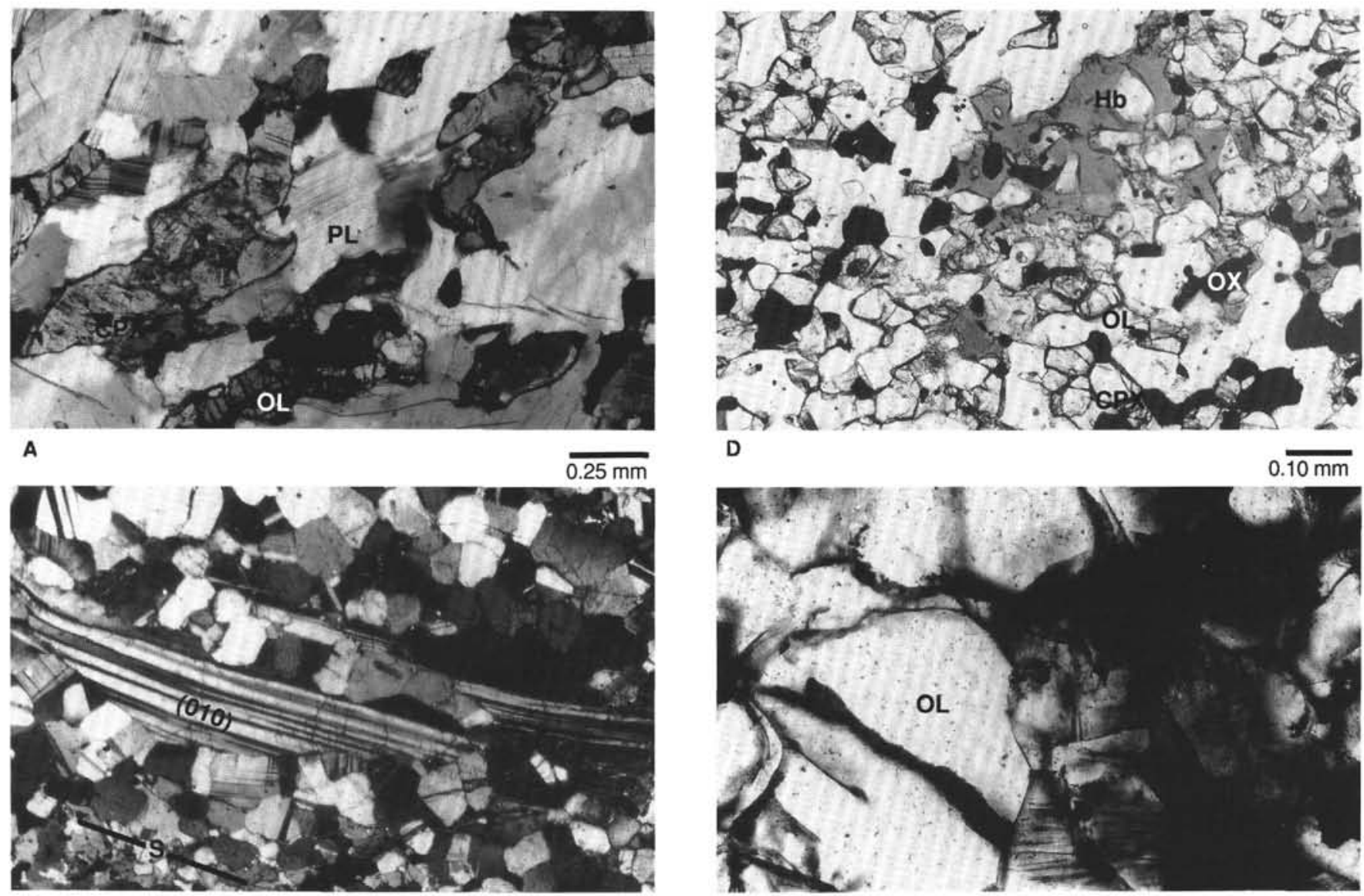

D

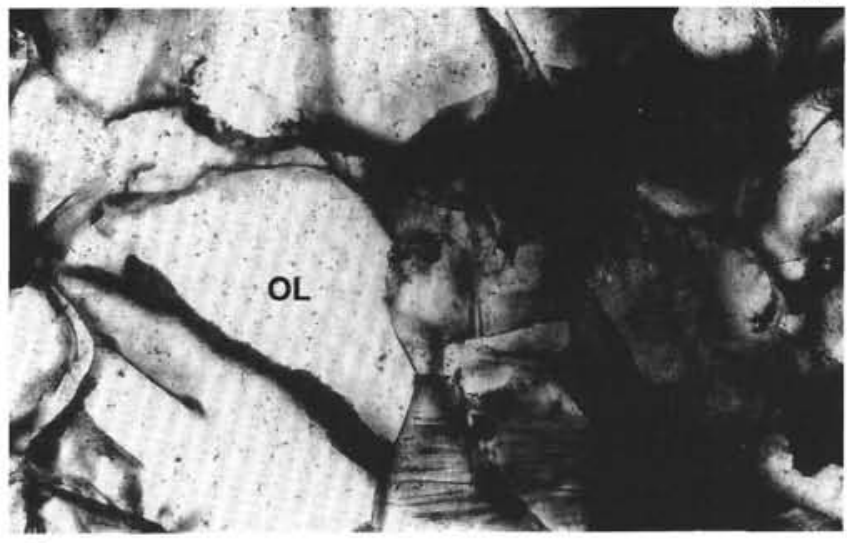

B

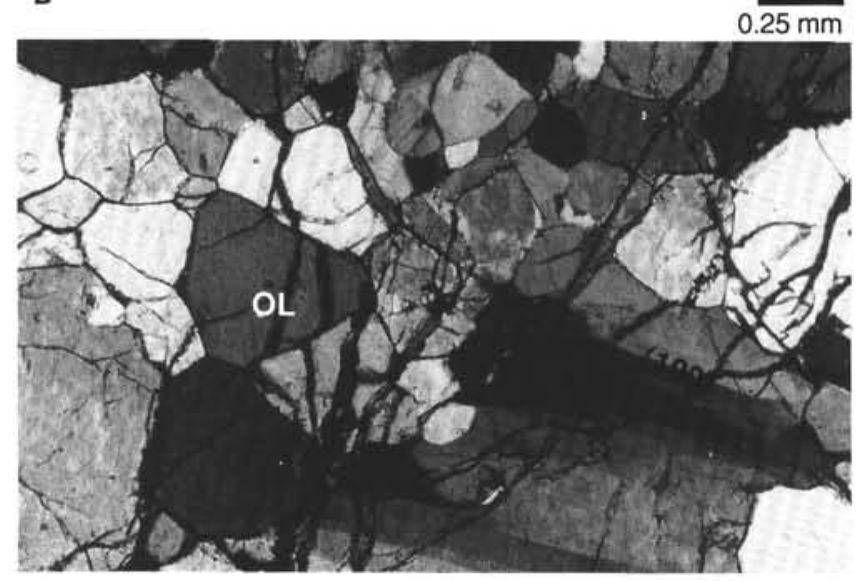

C

$0 . \overline{10 \mathrm{~mm}}$ 


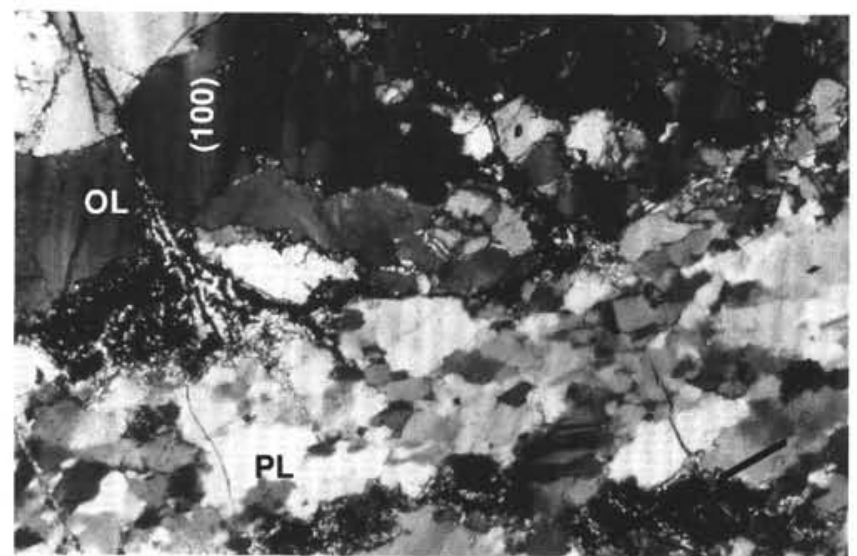

A

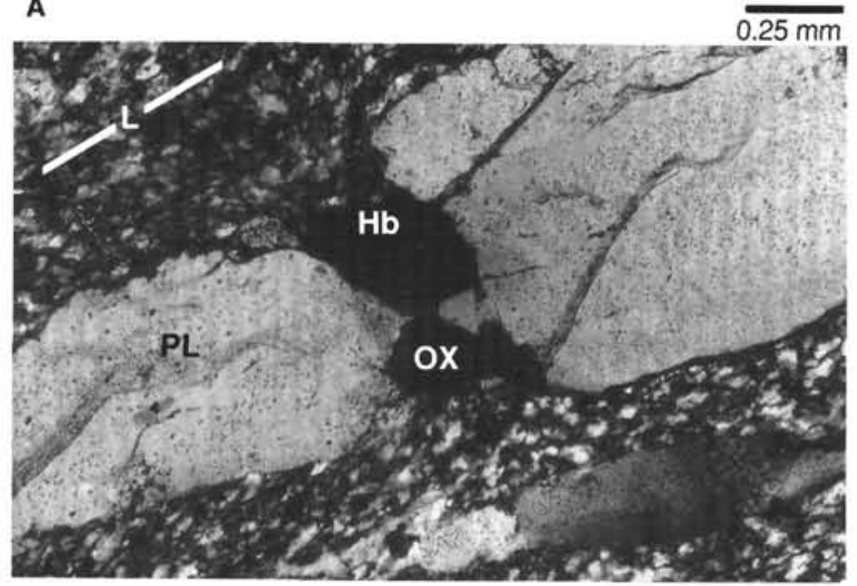

B

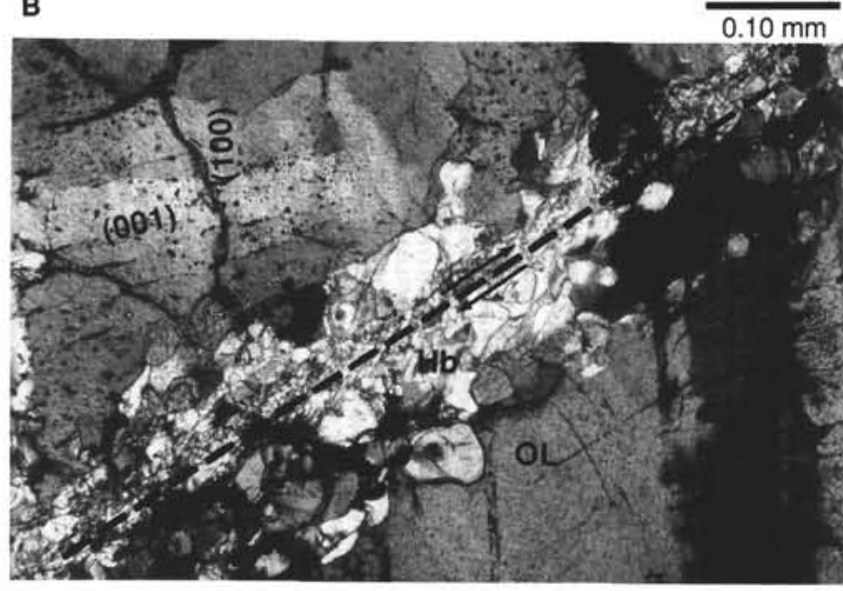

C

$0 . \overline{10 \mathrm{~mm}}$

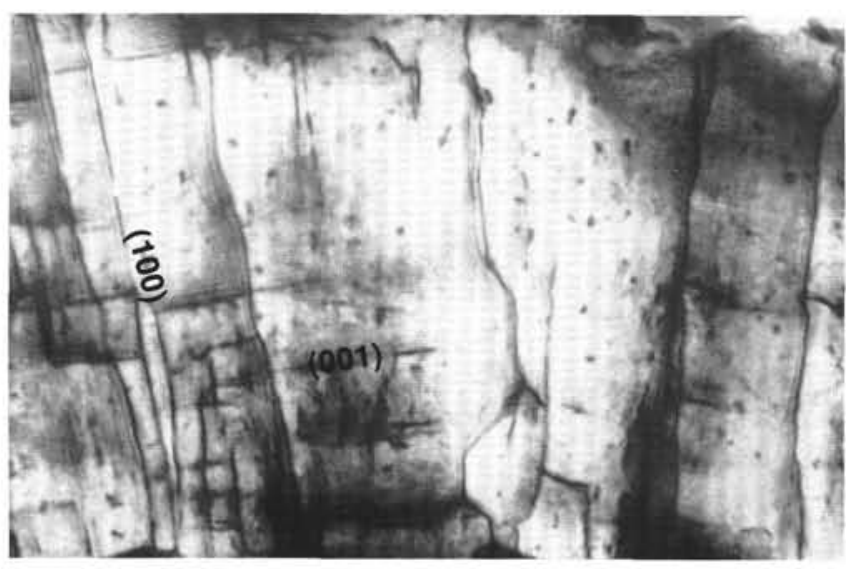

D

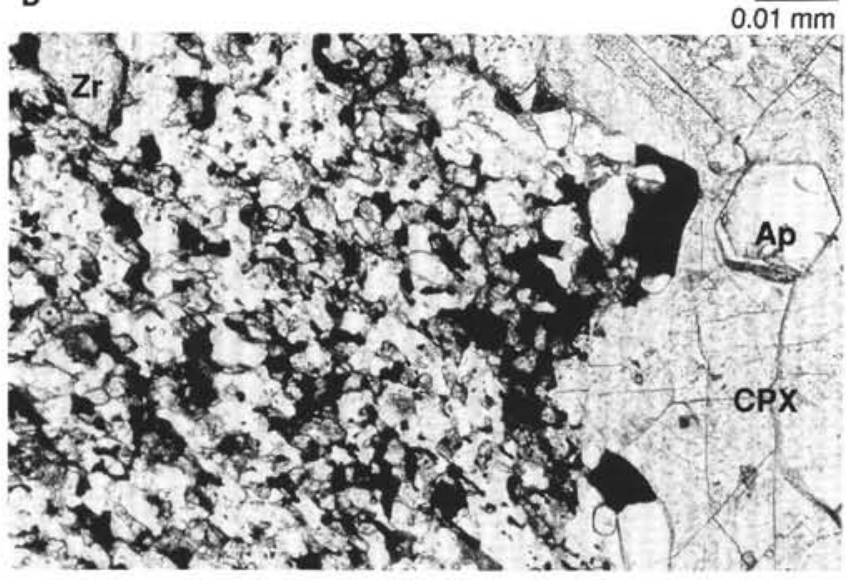

E

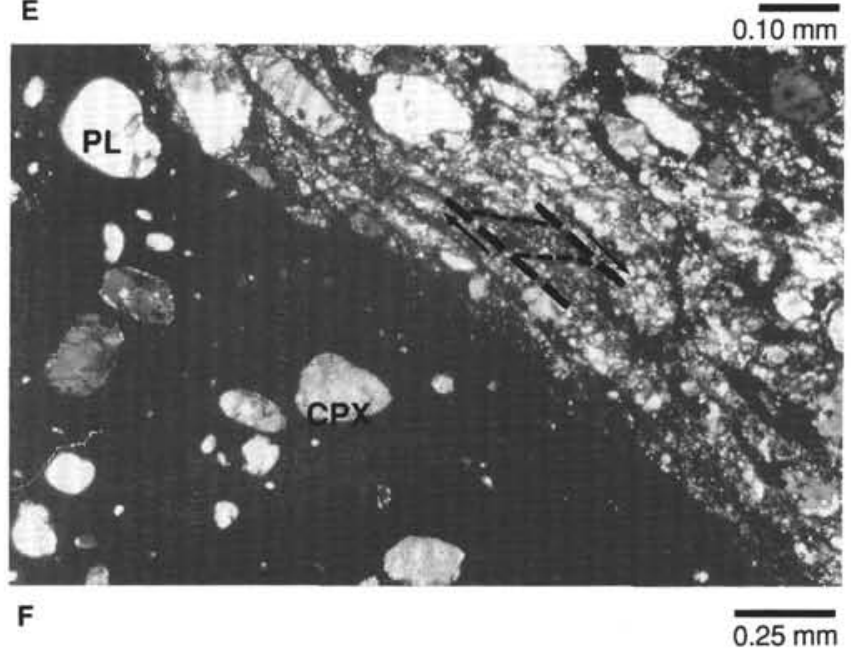

Figure 3. Photomicrographs from Site 735. A. Olivine and plagioclase grains elongated in the foliation (S) of Sample II8-735B-87R-5, 44-47 cm. Subgrain boundaries in olivine are produced by (100) dislocation walls. The plagioclase is recrystallized in small irregular neoblasts, and wavy extinctions are frequent; crossed nicols. B. Boudinaged plagioclase porphyroclast in finely recrystallized plagioclase matrix, Sample $118-735 \mathrm{~B}-8 \mathrm{D}-1,17-20 \mathrm{~cm}$. The crack is subperpendicular to the stretching lineation $(\mathrm{L})$ of the sample, and filled by green-brown hornblende and Fe-Ti oxide; crossed nicols. C. Fractured olivine crystal in Sample 118-735B-80R-5, 46-54 cm. The elongation of the hornblende grains in the sheared fracture indicates a dextral sense of shear in the photograph, corresponding to a normal offset in the sample. The olivine substructure is polygonized, with (100) and (001) dislocation walls (see Fig. 3D); crossed nicols. D. Detail of the polygonized dislocation substructure in the fractured olivine of Sample 118-735B-80R-5, 46-54 cm; oxidized sample. The (100) and (001) dislocation tilt walls isolate small square cells or subgrains; plane light. E. Coarse-grained Fe-Ti oxide-rich mylonite with clinopyroxene porphyroclast. Sample 118-735B-54R-1, 105-115 cm. See Figure $8 \mathrm{~A}$ for reflected light. The recrystallized assemblage comprises oxides, plagioclase, clinopyroxene, olivine, orthopyroxene, and apatite. Magmatic apatite (AP) is enclosed in the relict clinopyroxene porphyroclast. Note also the relict magmatic zircon ( $\mathrm{Zr}$ ) in the upper left; plane light. F. Fine grained Fe-Ti oxide-rich mylonitic band in Sample 118-735B-77R-1, 106-116 cm. See Figure 8B for reflected light. The plagioclase and clinopyroxene porphyroclasts are rounded and unstrained; in the less oxide-rich portion of the sample (upper right), the obliquity between thin oxide-rich shear planes and the foliation marked elongated recrystallized plagioclase indicates a normal sense of shear; crossed nicols. 
A

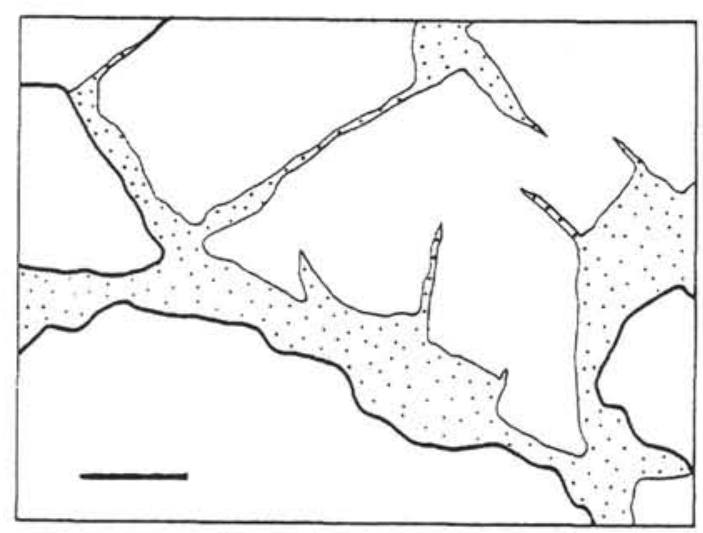

B

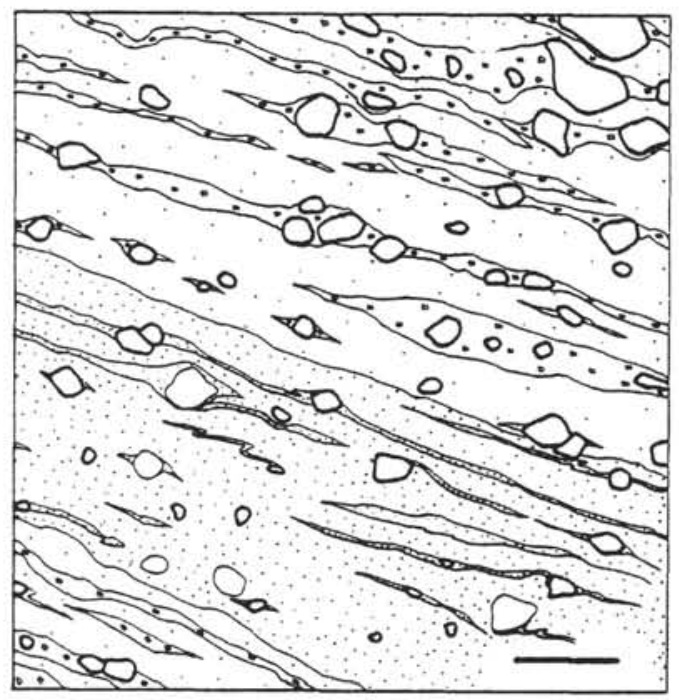

Figure 4. Sketches of deformed textures in the Site 735 gabbros. Scale bar is $1 \mathrm{~mm}$. Heavy contours: mafic porphyroclasts, mostly clinopyroxene; light contours: relict plagioclase; dots: recrystallized plagioclase; little squares: recrystallized mafic minerals. A. Sample 118735B-2D-2, 0-4 cm; weakly recrystallized, unfoliated. B. Sample 118-735B-3D-1, 46-49 cm; extensively recrystallized, mylonitic; closely spaced dots correspond to a band of finely recrystallized plagioclase and hornblende.

Because of the small size of the ODP samples, I was not able to cut the three orthogonal thin sections needed to ensure that plagioclase crystallographic fabrics are truly representative (Kruhl, 1987; Benn and Allard, 1989). However, less than 25\% of the plagioclase grains in the studied section exhibited no twins. I measured the optical directions of these untwinned grains and compared them with the optical fabric of the twinned grains. Both grain populations exhibit similar optical orientations, which suggests that the crystallographic fabric diagrams of Figure $5 \mathrm{~A}$ are reasonably representative.

A solid-state deformation large enough to produce this strong plagioclase crystallographic fabric presumably would also have resulted in an extensively recrystallized texture. It also seems unlikely that the clinopyroxene and olivine crystals could have been mechanically flattened in the foliation without breaking, recrystallizing, or developing a strong crystallographic preferred orientation. The observed foliation thus probably results largely from laminar flow of the incompletely crystallized magma (Benn and Allard, 1989). In this hypothesis, the crystals in suspension in the magma would tend to arrange with their large crystal faces parallel to the plane of viscous flow. This should produce the observed [010] concentrations perpendicular to the foliation (Figs. 5A and 5B), because (010) planes correspond to large crystal faces in both plagioclase and olivine. In samples showing a lineation, [100] in plagioclase may also tend to parallel the flow direction, because [100] often corresponds to the long axis of plagioclase crystals. The critical melt fraction separating this suspensionlike flow behavior from solid-state flow is probably about 30 vol\% (Van der Molen and Paterson, 1979). Below this critical value, the solidifying crystal mush behaved as a solid; continuing flow produced mechanical twins, grain-boundary migration, and limited recrystallization in plagioclase, as well as the dislocations observed in many olivine grains.

\section{SOLID-STATE PLASTIC DEFORMATION Deformed Gabbros Having Large Recrystallized Grain Sizes}

Deformed gabbros having large recrystallized grain sizes are most frequent in the lower part of the hole (Cannat et al., this volume). Magmatic minerals (plagioclase, clinopyroxene, olivine, orthopyroxene, $\mathrm{Fe}-\mathrm{Ti}$ oxides, and brown hornblende) have recrystallized into polygonal neoblasts that exhibit frequent triple junctions (Figs. 2B, 2C, and 2D). The grain size in monomineral olivine or plagioclase recrystallized aggregates is bimodal (Figs. 2B and 2C): small neoblasts ( 20 to $40 \mu \mathrm{m})$ are surrounded by larger grains (up to $0.2 \mathrm{~mm}$ in size). Most recrystallized plagioclase grains display mechanical twins (Fig. 2B). In olivine, the larger recrystallized grains are often free of dislocations (Fig. 2E), while most smaller neoblasts contain abundant free dislocations and dislocation walls. These small dislocation-rich grains appear to derive from the progressive misorientation of the subgrain boundaries formed by dislocation creep in the olivine porphyroclasts ("rotation recrystallization'"; Poirier and Nicolas, 1975; Fig. 2C). The larger, often dislocation-free neoblasts are thought to result from grain-boundary migration between dislocation-free and dislocation-rich grains or subgrains ("migration recrystallization"'; Poirier and Guillopé, 1979; Fig. 2E). The bimodal grain-size distribution of the plagioclase neoblasts is attributed to similar recrystallization mechanisms.

In polymineral recrystallized aggregates, grain size is uniform and moderate ( $\leq 50 \mu \mathrm{m}$; Fig. 2D), probably because recrystallized grains were prevented from growing by secondphase particles. Brown hornblende of probable magmatic origin (Stakes et al., this volume) is locally abundant. It has recrystallized in polygonal grains associated with clinopyroxene or $\mathrm{Fe}$-Ti oxide neoblasts, but it also formed poikiloblasts enclosing neoblasts of other mineral phases (Fig. 2D). This suggests that this hornblende crystallized just after the end of the deformation, from a fluid phase present along grain boundaries.

The plagioclase and olivine crystallographic fabrics are scattered (Fig. 6). In plagioclase (Fig. 6A), there is a faint concentration of [010] perpendicular to the foliation. This concentration is consistent with dislocation slip on $(010)$, as proposed by Ji et al. (1988) and by Ji and Mainprice (1988). It is also compatible with slip on an irrational plane perpendicular to the $\gamma$ optical indicatrix (Kruhl, 1989). Relict plagioclase porphyroclasts exhibiting this orientation of [010] are elongated in the foliation (Fig. 2B), but the recrystallized grains around them have more scattered crystallographic orientations. Most $(80 \%)$ of the plagioclase grains in the studied thin sections are twinned. The optical fabric of untwinned grains compares well with that of twinned grains. Specifically, the concentration of $\gamma$ (at about $30^{\circ}$ of [010] for $\mathrm{An}_{50}$; Burri et al., 1967) nearly perpendicular to the foliation is confirmed. 
A

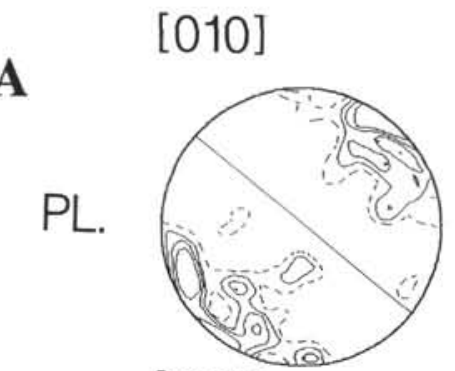

B

$$
\text { [100] }
$$

OL.

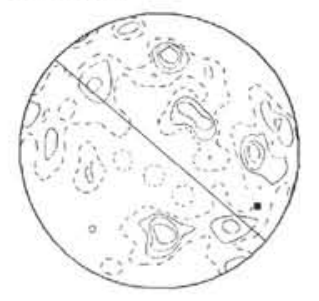

[001]

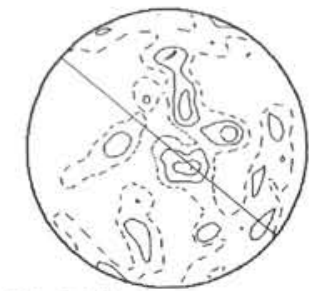

[001]

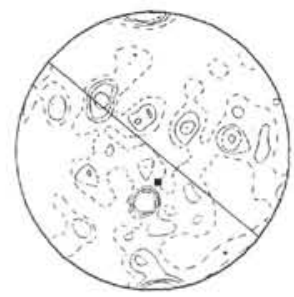

[100]
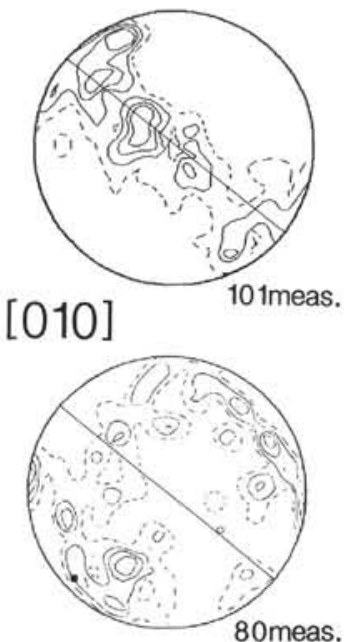

Figure 5. Viscous flow in the progressively solidifying magma. Plagioclase $\left(A_{35} 5\right.$ to $\left.A n_{45} 5\right)$ and olivine crystallographic fabrics from Sample 118-735B-38R-4, 10-15 cm. A. Plagioclase (PL) fabric (see text). B. Olivine (OL) fabric (see text). Lower hemisphere equal area projection. All diagrams in vertical plane; the arrow on the right side points upward. Line = trace of the foliation; the magmatic lineation is near downdip; black square $=$ best axis of the distribution. Contours: $1 ; 2 ; 3 ; 4 \%$ per $1 \%$ area.

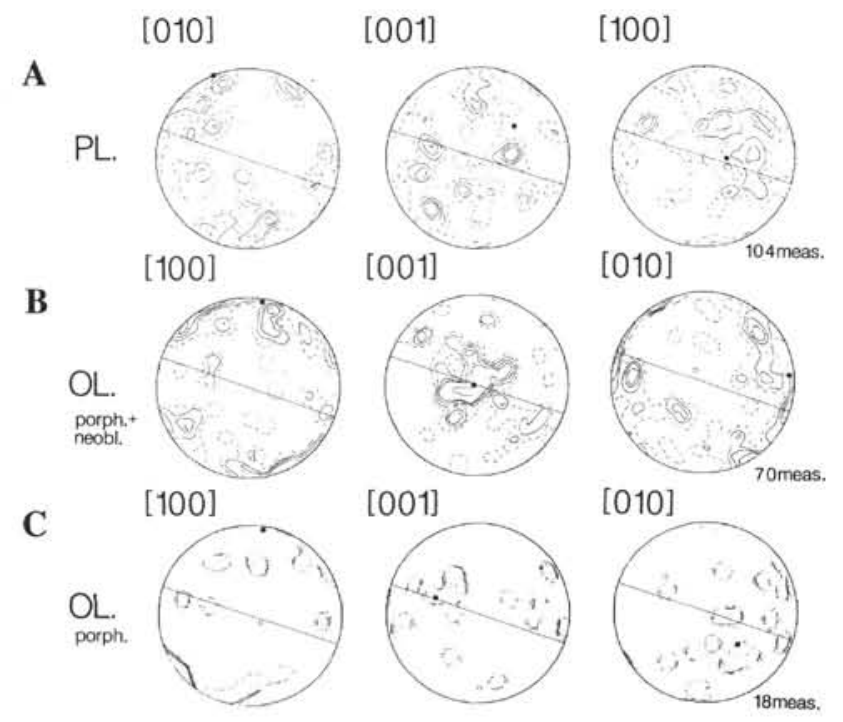

Figure 6. Deformed gabbro having large recrystallized grains. Plagioclase $\left(\mathrm{An}_{50}\right)$ and olivine crystallographic fabric from Sample 118-735B-80R-1, 11-17 cm. A. Plagioclase (PL) fabric (see text). B. Fabric of olivine $(\mathrm{OL})$ porphyroclasts and neoblasts. C. Fabric of olivine porphyroclasts alone (see text). Lower hemisphere, equal area projection. All diagrams in vertical plane, arrow pointing upward. Line $=$ trace of the foliation. The stretching lineation is downdip. Black square = best axis of the distribution. Contours are $1 ; 2 ; 3 ; 4 ; 8 ; 16 \%$ per $1 \%$ area.

The olivine porphyroclasts and some neoblasts exhibit well-defined subgrain boundaries (Fig. 2C), as a result of the piling up of dislocations in walls perpendicular to [100] (observed in oxidized samples; technique of Kohlstedt et al., 1976). This suggests that dislocation slip occurred along [100], the common slip direction in olivine deformed at high temperature (see Nicolas and Poirier, 1976). But the [100] axes in the fabric of the neoblasts and porphyroclasts (Fig. 6B) lie at a high angle from the foliation and lineation of the sample. The fabric diagrams in Figure 6C, including only the porphyroclasts, are similar. This suggests that the strain accommodated by dislocation creep was never large enough in a given grain to reorient the crystallographic fabric. This may result from the easy activation of the recrystallization mechanisms: as soon as some dislocations piled up in a grain, recrystallization occurred, producing new grains having an orientation similar to that of the original crystal. This process may have produced the observed crystallographic fabric (Figs. 6B and 6C), even after a large finite strain.

Easy activation of recrystallization mechanisms indicates high temperatures of deformation. This is consistent with the granulite facies metamorphic assemblages. The presence of a water-rich fluid phase along the grain boundaries during deformation, suggested by the poikilitic brown hornblende 
crystals (Fig. 2D), may further enhance grain-boundary migration. Based on hornblende compositions (Stakes et al., this volume), this fluid phase is thought to be magmatic in origin.

\section{Deformed Gabbros Having Small Recrystallized Grain Sizes}

Deformed gabbros having small recrystallized grain sizes are frequent in shear zones throughout the hole (Cannat et al., this volume). These shear zones often cut the deformed gabbros having larger recrystallized grains. They developed over a range of metamorphic conditions that covered the stability fields of upper to lower amphibolite-facies assemblages (Stakes et al., this volume). The deformed samples I have selected for this study exhibit upper amphibolite-facies metamorphic assemblages. Most magmatic minerals have recrystallized in these samples (plagioclase, olivine, clinopyroxene, brown hornblende, and $\mathrm{Fe}$-Ti oxides), but orthopyroxene grains are fractured, and green to brown hornblende of probable hydrothermal origin (Stakes et al., this volume) crystallized in the foliation. In shear zones developed in the stability conditions of actinolitic hornblende, small recrystallized plagioclase and oxide grains are also present, but the mafic minerals behaved in a brittle fashion.

The recrystallized plagioclase grains are irregularly shaped and 5 to $10 \mu \mathrm{m}$ in size (Fig. 2F). These grains appear to derive from the progressive misorientation of subgrains in the deformed crystals ("rotation recrystallization"; Fig. 2F). The recrystallized grain-size distribution is unimodal, and triple junctions are infrequent. This suggests that diffusion-controlled migration recrystallization (Poirier and Guillopé, 1979) was not very active. The deformed plagioclase grains have a good shape fabric, parallel to the foliation and lineation of the samples (Fig. 3A). These grains are rarely twinned, but exhibit pronounced undulatory extinction. Their preferred orientation is strong (Fig. 7A). Because of the absence of twinned grains, only the optical fabric could be measured. $\gamma$ (at $25^{\circ}$ of [010] for $\mathrm{An}_{45}$; Burri et al., 1967) is preferentially perpendicular to the foliation. $\beta$ (at $50^{\circ}$ of [001] for $\mathrm{An}_{45}$ ) tends to lie in the foliation, preferentially near perpendicular to the lineation. $\alpha$ (at $18^{\circ}$ of [100] for $\mathrm{An}_{45}$ ) is near to the lineation. This fabric is compatible with dislocation slip on (010) ( $\mathrm{Ji}$ et al., 1988; Ji and Mainprice, 1988), or on an irrational plane perpendicular to the $\gamma$ optical indicatrix (Kruhl, 1989). Note that this plagioclase crystallographic fabric does not account for the strong anisotropy of seismic velocities measured in some Site 735 deformed gabbros (Shipboard Scientific Party, 1989). These measurements indicate that the slowest direction of seismicwave propagation is often perpendicular to foliation. In plagioclase having a strong magmatic or solid-state fabric, the perpendicular to the foliation coincides with the maximum concentration of [010], which is thought to correspond with a fast direction of seismic-wave propagation in the feldspar crystals ( $\mathrm{Ji}$ and Mainprice, 1988). The concentration of the $\gamma$ optical indicatrix near the lineation (Fig. 7A) suggests that [100] may have acted as the dominant slip direction. Possibly, slip along [100] was favored in my samples by a preexisting magmatic fabric, with a lineation defined by the long axis ([100]) of the plagioclase crystals and parallel to the solid-state stretching lineation.

In the most extensively recrystallized samples, the shape and optical fabrics of plagioclase are still strong, and grains exhibit abundant subgrain boundaries. This indicates that dislocation creep and dynamic recrystallization remained the dominant flow mechanisms. But the relict plagioclase porphyroclasts elongated in this fine-grained recrystallized matrix are often fractured and boudinaged (Fig. 3B), even when their crystallographic orientation favored dislocation slip ( $\gamma$ perpendicular to foliation). This indicates that the recrystallized matrix was able to flow faster than the nonrecrystallized porphyroclasts. This strain-softening effect probably resulted from the continuous replacement through dynamic recrystallization of strain-hardened grains having abundant dislocations by annealed, dislocation-free neoblasts. Cracks in the broken plagioclase porphyroclasts are filled with green to brown hydrothermal hornblende (Stakes et al., this volume) and by secondary Fe-Ti oxides or sulfides (Fig. 3B).

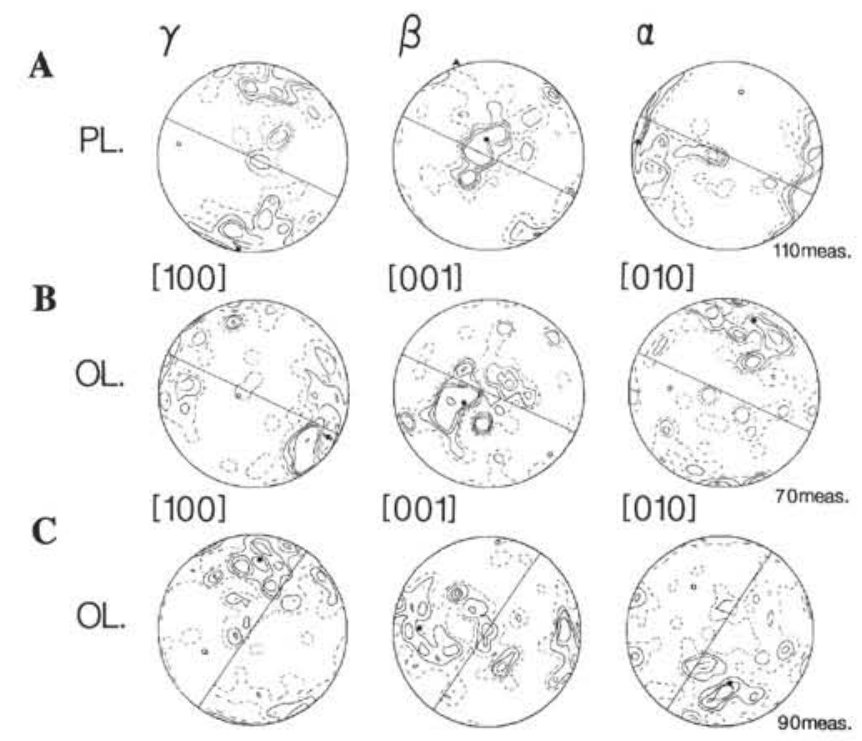

Figure 7. Deformed gabbros having small recrystallized grains. Plagioclase $(O L)$ and olivine $(O L)$ fabrics from Samples 118-735B-87R-5, 44-47 cm, and 118-735B-8D-1, 17-20 cm. A. Plagioclase $\left(\mathrm{An}_{40}\right.$ to $\left.\mathrm{An}_{45}\right)$; optical fabric in Sample 118-735B-87R-5, 44-47 cm. B. Olivine fabric (porphyroclasts and neoblasts) in Sample 118-735B-87R-5, 44-47 cm. C. Olivine fabric (porphyroclasts and neoblasts) in Sample 118-735-8D-1, 17-20 $\mathrm{cm}$. Projection conventions and symbols, same as Figure 6 . Contours: $1 ; 2 ; 3 ; 4 ; 8 \%$ per $1 \%$ area. 
Olivine porphyroclasts are elongated parallel to the lineation of the gabbro (Fig. 3A). They have closely spaced subgrain boundaries that correspond to (100) dislocation walls (observed in oxidized samples). Olivine is frequently recrystallized into polygonal grains 20 to $100 \mu \mathrm{m}$ in size. The dislocation substructure in these neoblasts is usually dense, but some grains are dislocation-free and probably result from migration recrystallization. The crystallographic fabric of both porphyroclasts and neoblasts is strong (Figs. 7B and 7C). This fabric corresponds to dislocation slip parallel to [100] on the (010) planes (Fig. 7B), or to a combination of the $(010)$ and (001) planes (Fig. 7C). The obliquity between [100] and the stretching lineation of the gabbro indicates a strong simple shear component (Bouchez et al., 1983) that corresponds to a normal offset in the two studied samples (Figs. 7B and 7C). The slip system identified in the olivine of the Site 735 samples has been activated experimentally at high, near-solidus temperatures (Raleigh and Kirby, 1970; Carter and Ave Lallemant, 1970; Phakey et al., 1972; Durham et al., 1977; Jaoul et al., 1979). During experimental deformation of olivine at lower temperatures, more compatible with the hornblende-bearing metamorphic assemblage observed in my samples, the dominant slip direction was [001] (Raleigh and Kirby, 1970; Carter and Ave Lallemant, 1970; Phakey et al., 1972). Note, however, that these experiments were performed at differential stresses and strain rates probably much higher than those that prevailed during the deformation of the Site 735 gabbros. For example, Phakey et al. (1972) conducted their experiments at differential stresses between 4 and $10 \mathrm{~kb}$ and strain rates about $10^{-5} \mathrm{~s}^{-1}$.

In samples containing the most extensively recrystallized plagioclase (Fig. 3B), the strain-softening effect that led to boudinage of the plagioclase porphyroclasts also caused brittle failure of the clinopyroxene, orthopyroxene, and olivine grains. These fractures are similarly filled with hornblende, and sometimes with secondary Fe-Ti oxides. They are either perpendicular to the stretching lineation, as in the case of the plagioclase porphyroclast shown in Figure $3 \mathrm{~B}$, or oblique on the foliation and sheared with a normal offset (Fig. 3C). Near the fractures, the olivine has a tightly polygonized substructure (Fig. 3C) caused by a dense array of (100) and (001) dislocation tilt walls (observed in oxidized samples; Fig. 3D). I propose that this strain-hardened substructure resulted either from the increased strain rate imposed on olivine by the surrounding recrystallized plagioclase, or from a progressive temperature decrease during the deformation. At this higher strain rate, or lower temperature (still within the temperature range of hornblende stability), dynamic recrystallization in olivine could not compete efficiently with the hardening effect of the piling up of dislocations. As a result, the olivine crystals became harder and harder to deform plastically and eventually broke.

In summary, the dominant flow mechanisms in deformed gabbros having small recrystallized grain sizes appear to have been dislocation creep and dynamic recrystallization of plagioclase. In olivine, dislocation creep along high-temperature slip systems produced strong crystallographic fabrics. Dynamic recrystallization_occurred through both rotation and migration processes. But this latter process may have been less active here than in the deformed gabbros having large recrystallized grain sizes. This is consistent with the metamorphic assemblages, which indicate amphibolite, rather than granulite, facies temperatures of deformation. In those intervals exhibiting extensive recrystallization of plagioclase, a strain-softening effect was observed. This effect is thought to have been controlled by dynamic recrystallization of plagioclase, and it led to brittle failure of both the plagioclase porphyroclasts and the mafic minerals (olivine and pyroxene). In addition, this effect was contemporaneous with circulation through the gabbros of a hydrothermal fluid crystallizing brown to green hornblende.

\section{Strain Localization: Deformation Processes in Site 735 Mylonites}

\section{Deformed Gabbros Having Large Recrystallized Grain Sizes}

In deformed gabbros having large recrystallized grains, a substantial reduction in grain size was observed in polymineral recrystallized aggregates (Fig. 2D, compared to Figs. 2B and $2 \mathrm{C}$ ). But mylonitic bands (i.e., narrow bands of high strain with reduced grain size; Bell and Etheridge, 1973) developed only in intervals containing more than about $10 \%$ oxides (Fig. $3 \mathrm{E})$. The modal proportions of oxides have been measured in four mylonite samples using the "Visilog" image-processing software (NOESIS, 1988), in microphotographs taken in reflected light (see Fig. 8). Minor quantities of recrystallized sulfides, present in all samples, are included in the oxide modal content. In these oxide-rich mylonites, ilmenite and magnetite recrystallized in euhedral grains 5 to $40 \mu \mathrm{m}$ in size and formed discontinuous streaks, with no preferred elongation (Figs. 3E and 8A) along grain boundaries of the other recrystallized minerals and of the rounded porphyroclasts. Recrystallized silicates are polygonal, equant, 10 to $40 \mu \mathrm{m}$ in
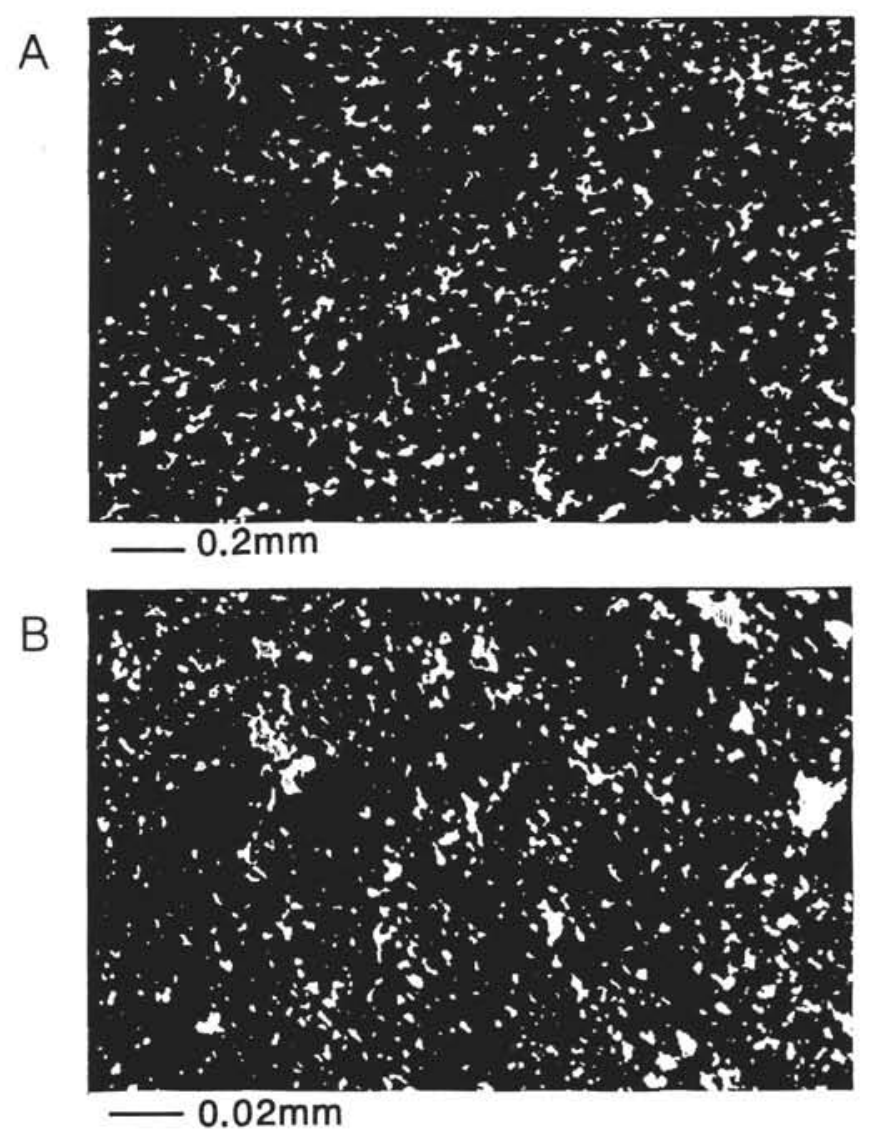

Figure 8. Fe-Ti oxide-rich mylonites in reflected light. A. Coarsegrained mylonite, oxide modal content: $10.9 \%$; Sample 118-735B$54 \mathrm{R}-1,105-115 \mathrm{~cm}$; see Figure 3E for transmitted light. B. fine-grained mylonite, oxide modal content: $12.6 \%$; Sample 118-735B-77R-1, 106$116 \mathrm{~cm}$; see Figure 3C for transmitted light. Oxide modal contents have been measured with "Visilog" image-processing software (NOESIS, 1988). 
size, and exhibit no crystallographic fabric. When present, olivine is dislocation-free. This indicates either that dislocation creep was not an active flow mechanism, or that the dislocation substructure was efficiently annealed by diffusioncontrolled migration recrystallization, as in the less-deformed surrounding gabbros. Relict porphyroclasts in these mylonites are rounded, show no preferred elongation, and are neither kinked nor fractured. They appear to have been passively rotated in the recrystallized matrix. The streaks of recrystallized oxides are not connected: they do not continuously surround the grain boundaries of the other minerals (Fig. 8A). Deformation thus is unlikely to have been controlled only by plastic flow in the ilmenite and magnetite crystals. But because only intervals containing more than $10 \%$ oxides are mylonitized, the oxides are thought to have played an important role in the activation of the strain-softening mechanisms, leading to the formation of mylonites. To account for the absence of foliation (Fig. 8A), the equant shape of the grains, the lack of crystallographic fabric and of a dislocation substructure (in olivine), and the passive rotation of the porphyroclasts, I propose that flow in these mylonites was controlled by mutually accommodating grain-boundary sliding and diffusion creep, as defined by Raj and Ashby (1971), Boullier and Gueguen (1975), and Gifkins (1976). According to these authors, reduced grain size, high temperature, and moderate deviatoric stresses favor these two deformation mechanisms. Diffusion creep may have been further enhanced by (1) the increased diffusivity of the grain boundaries between unlike phases; (2) the positive dependence of the diffusivity in oxides on the oxygen partial pressure (see Poirier, 1985), which may have been high in the studied samples because magnetite is abundant (the estimated ilmenite/magnetite ratio ranges from 1:2 to $2: 1$ in different samples and from place to place in a given sample); and (3) the dispersal of an aqueous fluid phase along grain boundaries during the deformation, suggested by the local presence of poïkilitic brown hornblende (Fig. 2D).

\section{Deformed Gabbros Having Small Recrystallized Grain Sizes}

In deformed gabbros having small recrystallized grain sizes, dynamic recrystallization of plagioclase in monomineral aggregates may have led to significant strain softening (see above paragraph). The resulting mylonites (Fig. 3B) are characterized by a strong shape and crystallographic fabric of plagioclase and by the development of sigmoidal tails around most relict porphyroclasts (Fig. 4B).

But the most spectacular mylonites developed in polymineral recrystallized aggregates containing abundant $\mathrm{Fe}-\mathrm{Ti}$ oxides and/or synkinematic hornblende. The Fe-Ti oxide-rich mylonites are almost completely opaque in transmitted light (Fig. 3F). This suggests a very high oxide content, but reflected light observations (Fig. 8B) revealed that the modal proportion of oxides in these mylonites is actually similar to that of the coarser-grained mylonites produced in granulite facies metamorphic conditions (Fig. 8A). Grain size is about 10 times smaller (Fig. 8), but the texture is about the same in the two types of mylonites: discontinuous streaks of recrystallized oxides (Figs. 8A and 8B), no foliation, and rounded and unstrained relict porphyroclasts (Fig. 3F). Apart from the oxides, the very fine-grained recrystallized matrix is composed of plagioclase and hornblende. Because of the opacity of the rock in transmitted light, the degree of crystallographic preferred orientation of these minerals is impossible to assess with the optical microscope. If this preferred orientation is strong, a possible flow mechanism may have been dislocation slip-accommodated grain-boundary sliding, as proposed by Etheridge and Wilkie (1979). Otherwise, I propose that this deformation may have been controlled by diffusion creep- accommodated grain-boundary sliding, as suggested for the coarser-grained mylonites.

\section{Origin of Oxides in the Mylonites}

The origin of oxides in the oxide-rich mylonites at Site 735 was discussed among the Leg 118 shipboard scientists (Shipboard Scientific Party, 1989). Was the oxide concentration in these mylonites primary, or did it result from channeling in shear zones of hydrothermal fluids rich in dissolved oxides?

There is evidence for remobilization of oxides by the water-rich hydrothermal fluids circulating in the gabbros before the end of deformation: oxides may be associated with green-brown hornblende in synkinematic cracks perpendicular to stretching lineation (Fig. 3B). However, the oxide-rich mylonites I have studied also contain abundant calcium-poor pyroxene (orthopyroxene or inverted pigeonite), locally abundant apatite, and scattered zircon (Fig. 3E). The apatite in these mylonites demonstrably recrystallized from magmatic apatite enclosed in the relict clinopyroxene porphyroclasts (Fig. 3E). These minerals are typical of undeformed oxide-rich intervals that exhibit preserved magmatic textures (Shipboard Scientific Party, 1989). Modal proportions of oxides in the mylonites (10\% to $18 \%)$ are well within the composition range of these oxide-rich undeformed gabbros (5\% to $25 \%$; Shipboard Scientific Party, 1989), and relative proportions of ilmenite and magnetite are similar (1:2 to $2: 1)$. I therefore propose that most oxides present in the mylonites $\mathrm{I}$ have studied derive from magmatic oxides through dynamic recrystallization.

\section{CONCLUSIONS}

Microstructural analysis of Site 735 gabbros suggests that some gabbros have been deformed in the crystal mush stage, before they had completely crystallized. This magmatic deformation produced a foliation and a strong plagioclase crystallographic fabric. Later, solid-state deformation occurred at progressively lower temperatures and increased availability of hydrothermal water, probably as the gabbros spread away from the ridge axis (Cannat et al., this volume). The microstructural study shows a sharp change of deformation processes in the gabbros as temperature decreased from the stability conditions of granulite-facies metamorphic assemblages to the stability conditions of amphibolite-facies metamorphic assemblages. Temperature-dependent diffusion processes may have controlled the deformation of all minerals in granulite-facies metamorphic conditions. Disorganized plagioclase and olivine fabric patterns characterize this granulite facies deformation. In contrast, dislocation slip in plagioclase appears to have been the leading flow mechanism in gabbros deformed in amphibolite-facies metamorphic conditions and produced strong plagioclase and olivine crystallographic fabrics. This change of deformation processes correlates with a marked size decrease of the recrystallized plagioclase grains. This reduction in recrystallized grain size is thought to result from an increase of the deviatoric stress, and thus from an increase of the yield strength of the gabbros.

During the deformation in granulite-facies metamorphic conditions, mylonites formed only in intervals containing more than $10 \%$ oxides. Strain-softening in these intervals may have been caused by the activation of diffusion creep-accommodated grain-boundary sliding. Most oxides in these mylonites are interpreted here as magmatic in origin. This suggests that strain localization leading to the formation of ductile faults in the deepest and hottest parts of the oceanic lithosphere may be influenced by the magmatic stratigraphy.

During the deformation in amphibolite-facies metamorphic conditions, dynamic recrystallization of plagioclase in very 
small neoblasts may have had a strain-softening effect, leading to formation of mylonitic bands and to brittle failure of the larger relict porphyroclasts (plagioclase, olivine, and pyroxene). Note that this brittle failure occurred at temperatures still within the stability range of brown to green hornblende.

\section{ACKNOWLEDGMENTS}

Many thanks to the students and staff of the Laboratoire de Tectonophysique, USTL, Montpellier (France), and especially to D. Mainprice and K. Benn, who allowed me to use their interactive program for measuring plagioclase fabrics, and to A. Nicolas, for his helpful comments about the manuscript. I also thank M. Boeuf, a student at UBO, Brest, for his help with the image-processing software, and J-L. Travers (UBO, Brest), for his help with the graphics. This work was financially supported by ODP-France.

\section{REFERENCES}

Bell, T. H., and Etheridge, M. A., 1973. Microstructure of mylonites and their descriptive terminology. Lithos, 6:337-348.

Benn, K., and Allard, B., 1989. Preferred mineral orientations related to magmatic flow in ophiolite layered gabbros.J. Petrol.,30:925946.

Benn, K., and Mainprice, D., 1989. An interactive program for determination of plagioclase crystal axes orientations from U-stage measurements: an aid for petrofabric studies. Computers and Geosciences, 15:1127-1142.

Bird, J. E., Mukherjee, A. K., and Dorn, J. F., 1969. Correlations between high temperature creep behavior and structure. In Brandon, D. G., and Rosen, R. (Eds.), Quantitative Relation Between Properties and Microstructure: Haifa, Israel, 255-342.

Bouchez, J-L., Lister, G. S., and Nicolas, A., 1983. Fabric asymmetry and shear sense in movement zones. Geol. Runds., 72:401419.

Boullier, A-M., and Gueguen, Y., 1975. SP-mylonites: origin of some mylonites by superplastic flow. Contrib. Mineral. Petrol., 50:93104.

Burri, C., Parker, R. L., and Wenk, E., 1967. Die optische Orientierung der Plagioklase: Basel (Birkhaüser).

Carter, N. L., and Ave Lallemant, H. G., 1970. High temperature flow of dunite and peridotite. Geol. Soc. Am. Bull., 81:2181-2202.

Durham, W. B., Goetze, C., and Blake, B., 1977. Plastic flow of oriented single crystals of olivine. 2. Observations and interpretations of the dislocation structures. J. Geophys. Res., 82:57555770.

Etheridge, M. A., and Wilkie, J. C., 1979. Grain size reduction, grain boundary sliding and the flow strength of mylonites. Tectonophysics, 58:159-178.

Gandais, M., and Willaime, C., 1984. Mechanical properties of feldspars. In Brown, W. L. (Ed.), Feldspars and Feldspathoids: NATO ASI Series, C-137, Reidel Dordrecht, 207-246.

Gifkins, R. C., 1976. Grain boundary sliding and its accommodation during creep and superplasticity. Metall. Trans., 7:1225-1232.
Jaoul, O., Gueguen, Y., Michaut, M., and Ricoult, D., 1979. A technique for decorating dislocations in forsterite. Phys. Chem. Mineral., 5:15-20.

Ji, S., and Mainprice, D., 1988. Natural deformation fabrics of plagioclase: implications for slip systems and seismic anisotropy. Tectonophysics, 147:145-163.

Ji, S., Mainprice, D., and Boudier, F., 1988. Sense of shear in high temperature movement zones from the fabric asymmetry of plagioclase feldspars. J. Struct. Geol., 10:73-81.

Kirby, S. H., 1985. Rock mechanics observations pertinent to the rheology of the continental lithosphere and the localization of strain along shear zones. Tectonophysics, 119:1-27.

Kohlstedt, D. L., Goetze, C., Durham, W. B., and Vander Sande, J., 1976. A new technique for decorating dislocations in olivine. Science, 191:1045-1046.

Kruhl, J. H., 1987. Preferred lattice orientations of plagioclase from amphibolite and greenschist facies rocks near the Insubric Line (Western Alps). Tectonophysics, 135:233-242.

1989. Natural deformation of plagioclase: implications for slip system and seismic anisotropy-a discussion on measuring and interpreting plagioclase preferred orientations. Tectonophysics, 166:345-350.

Mercier, J-C., Anderson, D. A., and Carter, N. L., 1977. Stress in the lithosphere: inferences from steady-state flow of rocks. Pure Appl. Geophys., 115:199-226.

Nicolas, A., and Poirier, J-P., 1976. Crystalline Plasticity and Solid State Flow in Metamorphic Rocks: London (Wiley Interscience).

NOESIS, 1988. "Visilog," a computer vision software: Versailles, France.

Phakey, P., Dollinger, G., and Christie, J. M., 1972. Transmission electron microscopy of experimentally deformed olivine crystals. In Heard, H. C. (Ed.), Flow and Fracture of Rocks. Geophys. Monogr. Ser., 16:117-138.

Poirier, J-P., 1985. Creep of Crystals. High Temperature Deformation Processes in Metals, Ceramics and Minerals: Cambridge (Cambridge Earth Sci. Ser.).

Poirier, J-P., and Nicolas, A., 1975. Deformation-induced recrystallization by progressive misorientation of subgrain-boundaries, with special reference to mantle peridotites. J. Geol., 83:707-720.

Poirier, J-P., and Guillopé, M., 1979. Deformation-induced recrystallization of minerals. Bull. Minéral., 102:67-74.

Raj, R., and Ashby, M. F., 1971. On grain boundary sliding and diffusional creep. Metall. Trans., 2:1113-1127.

Raleigh, C. B., and Kirby, S. H., 1970. Creep in the upper mantle. Mineral. Soc. Am. Spec. Pap., 3:113-121.

Shipboard Scientific Party, 1989. Site 735. In Robinson, P. T., and Von Herzen, R., et al., Proc. ODP, Init. Repts., 118: College Station, TX (Ocean Drilling Program), 89-212.

Twiss, R. J., 1977. Theory and applicability of a recrystallized grain size paleopiezometer. Pure Appl. Geophys., 115:227-244.

Van der Molen, I., and Paterson, M. S., 1979. Experimental deformation of partially melted granite. Contrib. Mineral. Petrol., 70:299-318.

Date of initial receipt: 11 July 1989

Date of acceptance: 14 March 1990

Ms 118B-134 